\title{
Stress Management Training for Working, Elderly, and Health Cadre Women: Rumah Pendamping Emak Sehat Jiwa
}

\author{
Kelly Irawati ${ }^{*}$, Arif Wahyu Setyo Budi, Fahni Haris \\ Nursing Study Program, Faculty of Medicine and Health Science, Universitas Muhammadiyah Yogyakarta, \\ Indonesia
}

Submitted: January 20 2020 ; Revised: June 22 ${ }^{\text {th }}$ 2020; Accepted: May $03^{\text {rd }} 2021$

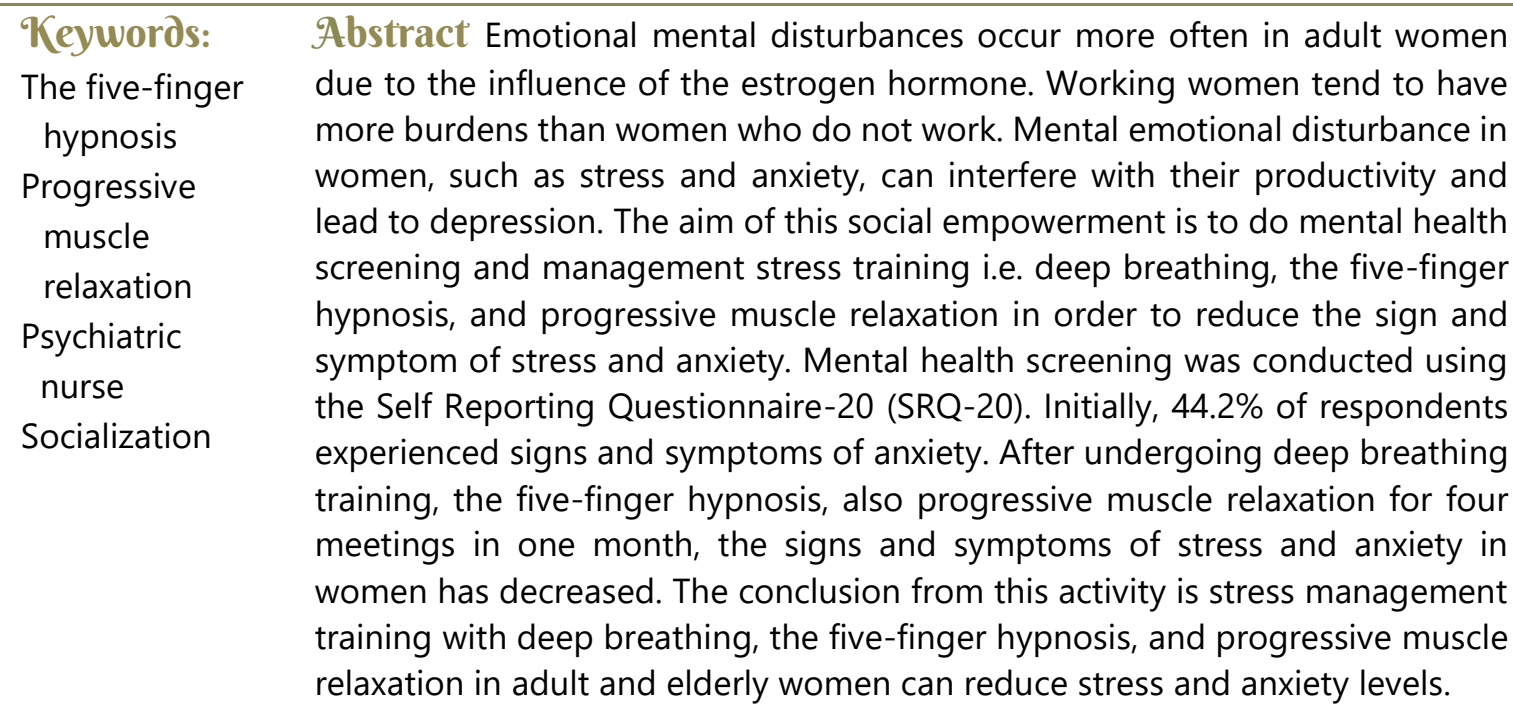

\section{INTRODUCTION}

From 2013 to 2018, mental emotional disorder among people aged over 15 years in Indonesia increased to 9.8 per million population (Ministry of Health, 2018). The Special Region of Jogjakarta has a mental emotional disorder rate of seven per million population (Ministry of Health, 2018). Emotional mental disturbance occurs more easily among adult or pre-menopause women. This mental disorder occurs due to changes in menstrual irregularities, fatigue, and a burning sensation in the face and neck (Widaryanti \& Dewi, 2017). Women, especially wives, are very susceptible to psychological disorders because of their changing roles as wives and mothers.

Females who have dual roles as housewives and working women certainly have a different burden from women who do not work. However, working can be a means of self-actualization and releasing fatigue from domestic problems (Pujiastuti \& Retnowati, 2004). Mental emotional disorder in women is caused by several factors, namely physical and psychological factors, as well as a change in the role of a single (young) woman into a woman who has family responsibilities and a woman who works.

Working is an activity that can be a medium for calming down from family problems. However, when the work's demands are greater than the responsibility of caring for the family, it can trigger conflict between a husband and wife (Amanda \& Mujiasih, 2017). The wife's stress level significantly decreases if her husband provides social support (Widaryanti \& Dewi, 2017).

Mental health problems in women result from several aspects, comprising economic factors, family problems, and work problems. The results of mental health screening conducted by students on February 24,

ISSN 2460-9447 (print), ISSN 2541-5883 (online)

*Corresponding author: Kelly Irawati

Nursing Study Program, Faculty of Medicine and Health Science, Universitas Muhammadiyah Yogyakarta, Jl. Lingkar Selatan (Brawijaya), Tamantirto, Kasihan, Bantul, DIYogyakarta 55183, Indonesia

Email: kellyana@umy.ac.id 
2019 showed that working mothers had greater pressures, so that they were at a higher risk of experiencing mental emotional disorder. The problems that often occur in working mothers can manifest as anxiety, self-concept disorder, sleep disorder, and depression.

Mental emotional disorder in a mother can also be caused by the absence of social support to be able to communicate her problems (Widaryanti \& Dewi, 2017). The society tends to underestimate a mother's complaints. It can be concluded that the problem of mental disorders in mothers is very likely to occur and requires emotional support for them to deal with it.

People often refer to emotional mental disorder as stress. Stress is an individual psychological condition caused by pressures in the surrounding environment (Broerman, 2018). Some study showed that there was a significant interaction of polygenic risk score with women's personal life events that contribute positively to the risk of depression (Colodro Conde et al., 2019). According to the theory of diathesis stress, a woman is more susceptible to stress or depression due to pressures from their surrounding environment.

Handling cases of mental disorders in mothers and their families has not received a full or urgent attention in the Indonesian society. This is due to the perception that the problem of mental disorders is still taboo. This created an obstacle for health workers to make further efforts. In fact, the problem of mental disorders has become a disability problem, which has a damaging impact on the development of the society.

This problem underlay the initiation of this community service program, whose aim was to deal with mental disorders in mothers and families by carrying out counseling and home therapy for mothers and their families. This community service targeted working or unemployed women or mothers. In other words, the targets of this program were women, both those in productive age and the elderly. This community service engaged in dealing with the problem of psychosocial disorders using stress management comprising deep breathing, five-finger hypnosis, and the progressive muscle relaxation. The target women had never experienced any of these treatments. Therefore, the community service team hoped that these treatments would be able to help reduce the problem of their psychosocial stress and anxiety disorders.

Stress is a stimulus that challenges, threatens, and calls for an individual's attention. An individual needs more energy to deal with stress, and dealing with it influences his/her vital signs (Stuart, 2013). Stress is characterized by fatigue, feelings of uncertainty, unable to rest, irritability, and feelings of wanting to be angry (Townsend, 2011). Stress can be defined as a threatening situation that calls for someone's attention and requires a lot of energy to overcome.

Stress and depression symptoms in women are influenced by the environment as well as genetic interactions in an individual (Arnau-Soler et al., 2019). Stress can occur due to several factors, including predisposing factors consisting of biological, psychological, and socio-cultural factors. Biological factors for stress include genetic history, nutritional status, general health conditions, and exposure to toxins. According to the diathesis stress model, susceptibility to stress is caused by environmental stressors in early life or due to interactions between heredity and the environment (Psychology, 2020) Psychological factors can be related to the ability to communicate, intelligence, morals, personality, past experiences, self-concept, motivation, psychological defense, and coping mechanisms.

The factors of socio-cultural stress are age, gender, education, income, occupation, social position, cultural background, belief or religion, social relations, and position in politics (Stuart, 2013). Stress can also arise due to several precipitating factors, including biological, psychological, and socio-cultural factors. The triggering factors are classified based on their forms (natures), origins, time of appearance (timing), and the frequency of the appearance (Stuart,2013).

Stress management is a method to reduce psychological stress. Some stress management tools that can be used are deep breathing, the five-finger hypnosis, and progressive muscle relaxation. Progressive muscle relaxation is the simplest method of relaxation by tensing and relaxing the muscles of the body. Progressive muscle relaxation techniques, simply called relaxation, is done by stretching muscles then relaxing the muscles in one part of the body at a time to provide a feeling of physical relaxation (Rochmawati, 2017). Progressive muscle relaxation is an easy stress management tool apart from deep breathing, and the five-finger hypnosis.

The five-finger hypnosis is a way of hypnotizing oneself that can cause a high relaxing effect, thereby reducing stress and tension (Febtrina \& Malfasari, 2018). This hypnosis is a generalist therapy that is carried out by clients. During this therapy, one is thinking about pleasant experiences with their own five fingers, so that she/he can reduce her/his anxiety, lower his/her blood pressure, and improve his/her sleep quality (Syukri, 2019). The five-finger hypnosis can be regarded as one of the treatments or therapies used for relaxation, calming, and reducing anxiety. The fivefinger hypnosis is more beneficial for the body if the person doing this is also breathing relaxedly and deeply. 
Deep breathing is a relaxation method that helps a person to relax, calm, and reduce his/her anxiety by inhaling oxygen through the nose and exhaling it through the mouth. Deep breathing relaxation is a relaxation therapy that is done by controlling breathing using an appropriate periodic count, so that it is effective in reducing depression and anxiety as well as increasing calmness (Kusyati, Santi, \& Hapsari, 2018).

The elderly, who are also known as senior citizens, usually have decreased cognitive function and memory. The elderly are individuals who are more than 65 years old. They can also be divided into three groups, namely youngest-old group (65 to 74 years), middle-old group ( 75 to 84 years), and oldest-old group whose members are 85 years old and above. Elderly people will experience many symptoms in terms of their reproduction system, bladder control, ability to move due to their reduced knee muscle strength, and their ability to socialize outside their homes or in their social environment, which will decline (Eliopoulos, 2018).

Older people experience a decrease in making responses during communication and experience a decline in memory. These conditions trigger mental and emotional disorders, even depression (Stuart, 2013). An elderly person is very susceptible to depression or stress due to their reduced body functions, decreased reproductive capacity, and decreased social skills.

\section{METHODS}

This community service activity utilized health education methods, followed by stress management training for elderly cadres (Kader Posyandu Lansia), elderly women, and adult women. The health education contained materials related to the psychosocial and mental health in women and stress management. The training program during the community service was related to stress management. The training was carried out by means of the five-finger hypnosis, deep breathing, and progressive muscle relaxation. This activity aimed to provide understanding to elderly cadres and women who are in productive age about psychosocial health, explain how to care for their mental and emotional health, and teach them how to independently deal with their stress or psychosocial health problems. This community service program was named Rumah Pendamping Emak (Ibu) Sehat Jiwa, and it could also be called Ramping Emak Sejiwa. This program had three stages: preparation stage, implementation stage, and evaluation stage.

The total number of participants in this community service was 52 people, who were all female. This was in accordance with the objective of the community service program, which was to assist women in maintaining their mental health, especially in maintaining their mental and emotional health. The majority of participants $(73 \%)$ were in the elderly category as can be seen in Table 1 . The results of the participants' blood pressure measurements show that $67.3 \%$ of them had high blood pressure.

Table 1. The characteristics of participants of Ramping Emak Sejiwa $(n=52)$

\begin{tabular}{|c|c|c|c|}
\hline No & Respondent Characteristic & Frequency & Percentage \\
\hline \multirow[t]{5}{*}{1} & Age & & \\
\hline & a. Late Adulthood & 4 & 7.7 \\
\hline & b. Middle Adulthood & 10 & 19.2 \\
\hline & c. Elder People & 38 & 73.1 \\
\hline & Total & 52 & 100 \\
\hline \multirow[t]{5}{*}{2} & Blood Pressure & & \\
\hline & a. Low & 9 & 17.3 \\
\hline & b. Normal & 8 & 15.4 \\
\hline & c. High & 35 & 67.3 \\
\hline & Total & 52 & 100 \\
\hline
\end{tabular}

\subsection{Preparation stage}

The preparation of Ramping Emak Sejiwa started with the preparation of cadres from local women in Kalirandu Hamlet, RT 07 and RT 09, to ensure that these participants fit the targeted criteria. The place and media were prepared according to the targets' needs. The community service team anticipated the possibility that some participants could not always attend the training activities. In this preparation stage, some team members also coordinated with village officials, including the dukuh (head of hamlet), the head of elderly cadres, and some of the elderly cadres. Ramping Emak Sejiwa was carried out in Kalirandu Hamlet in a house, pavilion, or Posyandu (an integrated health service unit) in the hamlet. The community service team also provided resource persons or practitioners who were psychiatric-mental health or specialists to present the materials and provide the training. Stress management training with the five-finger hypnosis, 
deep breathing, and progressive muscle therapy combined with exercise activities for the elderly was organized in Apsari Hall, Kalirandu Hamlet, Bangunjiwo Village.

\subsection{Program implementation}

The program implementation of Ramping Emak Sejiwa began with mental health screening of targeted mothers and the elderly using the Self Reporting Questionnaire 20 (SRQ-20). The implementation of the whole program lasted for four weeks, which was divided into four sessions. The first session was a mental health screening followed by a presentation of materials about mental health. The results of the mental health screening were then classified according to the level of the participants' mental and emotional disorders, namely: mild, moderate, and severe. The second session was the five-finger hypnosis stress management training, deep breathing, and progressive muscle relaxation accompanied by the use of the murotal strains of the Ar-Rahman. This training was tailored based on the results of the mental health screening. Participants with mild emotional and mental disorders received deep breathing therapy. Those with moderate mental and emotional disorders were given the fivefinger hypnosis therapy, while participants who had severe emotional and mental disorders received progressive muscle relaxation therapy. The third session consisted of evaluating stress management training carried out in the second session, training the participants to do the therapies independently, and providing opportunities for them to try to do the therapies independently. In the third session, all participants were trained to do deep breathing stress management, the five-finger hypnosis, and progressive muscle relaxation. The last session consisted of the evaluation of the training outcomes in sessions two and three followed by a post-test, which was aimed to assess the participants' mental health using the SRQ-20. The time allocated for each of the sessions was 45 to 60 minutes

\subsection{Data collection and data analysis}

The initial screening was done using Self Reporting Questionnaire 20 (SRQ-20) followed by the stress management training. The second group of data was collected after the training using a post-test. The initial screening was done to gather information on the initial condition of the participants' mental and emotional health. The results of the initial screening could determine the distribution of mental health classifications, and then the participants were given the training according to conditions. After the participants completed their training, the second group of data was gathered using the SRQ-20.

\subsection{Time, location, and duration}

The community service program was carried out for four weeks from March to April 2019. The participants were given materials and training on deep breathing stress management, the five-finger hypnosis, and progressive muscle relaxation for four weeks. The session was scheduled every Sunday in accordance with the elderly's exercise schedule at the Posyandu Kalirandu. The location of the training was in the Apsari Hall in Kalirandu Hamlet, Bangunjiwo Village, Kasihan Subdistrict, Bantul Regency. This activity was attended by 52 participants consisting of adult and elderly women as well as the posyandu's elderly cadres.

\subsection{Data analysis}

The collected data were analyzed using SPSS software through both univariate and bivariate test, namely paired sample t-test. The characteristics of the participants were their ages and blood pressures. The results of the mental health screening before and after the stress management training consisting of deep breathing technique, the five-finger relaxation, and progressive muscle relaxation were also processed using SPSS by looking at the mean of the signs and symptoms scores that were exhibited by the participants.

\section{RESULTS AND DISSCUSION}

Table 2 shows the results of blood pressure measurement and mental health screening in the adult women and elder women of Kalirandu Hamlet before and after the management stress training Ramping Emak Sejiwa $(\mathrm{n}=52)$

Table 2. Results of blood pressure measurement and mental health screening

\begin{tabular}{lllll}
\hline \multirow{2}{*}{ Variable } & \multicolumn{2}{l}{$\begin{array}{l}\text { Intervention } \\
\text { Mean (SD) }\end{array}$} & \multirow{2}{*}{$\begin{array}{l}\text { Mean } \\
\text { difference }\end{array}$} & $\begin{array}{l}\text { P } \\
\text { Value }\end{array}$ \\
\cline { 2 - 3 } & Before & After & & \\
\hline $\begin{array}{l}\text { Systole } \\
\text { blood }\end{array}$ & 143.21 & 121.29 & 21.92 & 0.001 \\
pressure & $(23.42)$ & $(12.49)$ & & \\
\hline $\begin{array}{l}\text { Mental } \\
\text { Health }\end{array}$ & 0.65 & 0.06 & 0.59 & 0.001 \\
\hline
\end{tabular}

Table 2 shows that there was a decrease of $21.92 \mathrm{mg} / \mathrm{dl}$ of systolic blood pressure after the stress management intervention. The results of the initial mental health screening showed that there were participants who had signs and symptoms of mental emotional disorders. The mental health screening in the community service program was done using the SRQ-20 which contains 20 signs of mental emotional symptoms experienced by individuals in the last 30 days. The symptoms shown by most of the participants in the last thirty days were frequent headaches, insomnia, loss of appetite, restlessness, and being easily scared. These symptoms were identified as some signs or symptoms of anxiety. 
The majority of the participants in this community service activity were adult women who had families. The stress and anxiety felt by the participants arose because they were thinking about their children's school fees, how to manage money, conflicts with their spouses, job demands in factories where they worked, and other family problems. The participants were prone to stress and anxiety because they did not know how to cope with them and reduce the signs and symptoms.

Physiological signs or symptoms of anxiety negatively affect the people's work performance and their gastrointestinal system. With regard to the latter, the symptoms can appear as reduced appetite, feeling uncomfortable in the stomach, abdominal pain, diarrhea, nausea, and vomiting. These can be accompanied by behavioral symptoms such as irritability, inability to rest, tremors, inability to coordinate, and restlessness (Stuart, 2013). The signs and symptoms of anxiety that are felt by the participants were also in accordance with the characteristics of anxiety, namely insomnia, unable to rest, irritability, fear, confusion, lack of appetite, and discomfort in the stomach (NANDA, 2018). The signs and symptoms of anxiety experienced the training participants could also be influenced by old age.

Most participants who took part in this community service program were elderly women or over 45 years of age. The findings in this community service are consistent with those of other studies that show that elderly women tend to experience signs and symptoms of anxiety due to commodities and increasing age (Solvik et al., 2019). The findings in this community service are also in line with those of studies which show that fatigue and exacerbation of anxiety in women are caused by the luteal phase of the menstrual cycle, which has periods that are prone to emotional mental disorders (Li et al., 2019). The signs and symptoms of anxiety that were identified in the community service participants appeared due to their increasing age and the presence of hormonal factors that occurred in their menstrual phase or the shift from premenopausal phase to the menopause phase.

Anxiety disorders that arose in the training participants could also be caused the fact that they had reached menopause phase. This may have triggered the symptoms of anxiety, consisting of lack of appetite, irritability, difficulty resting, and easily getting tired. In line with research conducted by Widaryanti, it is explained that women in menopause or the elderly who have physical disorders can suffer from psychological disorders such as anxiety, irritability, and decreased self-confidence, and in turn these can lead to stress in these women (Widaryanti \& Dewi, 2017). The majority of the participants in this community service program were elderly women who were prone to anxiety attacks and signs or symptoms of stress because they had reached menopause.

During the training the participants were trained to reduce their anxiety and signs of stress through three methods, which were the five-finger hypnosis stress management, deep breathing, and progressive muscle relaxation. The signs and symptoms of anxiety in the participants decreased as evidenced by the results of the two screenings carried out before and after they were trained in progressive muscle relaxation. The post-test results are in line with studies asserting that stress management with progressive muscle relaxation can reduce anxiety levels in breast cancer patients (Nova \& Tumanggor, 2018). The outcomes of this exercise are also supported by research findings suggesting that progressive muscle relaxation can reduce stress in families caring for mental patients ( $\mathrm{PH}$, Daulima, \& Mustikasari, 2018). Progressive muscle relaxation management can be applied to reduce stress and anxiety levels in the elderly, patients with breast cancer, and in families caring for mental patients.

Another stress management used in this training was deep breathing technique. Deep breathing has been shown to reduce stress and anxiety, and this is supported by research findings indicating that deep breathing therapy and aromatherapy can lower blood pressures (Kusyati et al., 2018). The stress management through deep breathing technique in this training was successful, and this is supported by research findings suggesting that deep breathing relaxation intervention and the five-finger hypnosis can reduce anxiety levels compared with stress management through health education using leaflets (Febtrina \& Malfasari, 2018). The stress management methods used in the community service program for mothers have also been proven successful by several studies.

It can be argued that stress management through progressive muscle relaxation, deep breathing, and the five-finger hypnosis is easy to learn, and it does not require hard-to-find media. Therefore, these techniques do not increase the stress and anxiety level of the participants when they plan on doing it. The five-finger hypnosis practiced in this training had also been shown to reduce stress and anxiety levels. One of the studies whose findings support the training program in this community service argues that the decrease in anxiety among hypertensive patients was very significant after they underwent the five-finger hypnosis therapy (Syukri, 2019). The five-finger hypnosis has also been carried out by Hartono in his research, and coupled with a spiritual approach this technique was proven successful in reducing insomnia among the elderly, the research participants (Hartono, Somantri, \& Februanti, 2019). 
The five-finger hypnosis stress management has been studied by several health professionals and has shown significant results in reducing signs and symptoms of stress and anxiety such as increased blood pressure and sleeping difficulty in the elderly. This hypnosis therapy is a relaxation technique that provides a relaxing effect on the autonomic nervous system to maintain blood supply to the muscles and reduce oxygen consumption, heart rate, sweat, and muscle activity by using the power of the mind and moving the body so that the patient becomes more relaxed (Hartono, Somantri, \& Februanti, 2019). In a study conducted by Wahyudi, it was shown that the fivefinger relaxation could normalize the respiratory rate in patients who experienced pain due to fractures (Wahyudi et al., 2019).

The decrease in the signs and symptoms of anxiety in the community service participants could also be influenced by external stimuli other than the stress management techniques they used during the training. These stimuli may have been increased family support, the participants' good mood, and improved sleep quality. Wahyuni (2017) said that there is a positive correlation between anxiety and the quality of sleep of pregnant women. Other studies show that there is a relationship between the level of anxiety and the quality of sleep among the elderly in Posyandu Permadi, Tlogo Mas Village, Malang City (Witriya, Utami, Andinawati, 2016).

Good sleep quality can be understood as a factor that can reduce anxiety levels in pregnant and elderly women. Another factor that may have supported the decrease in anxiety levels in women and the elderly in this program was the participants' consistency in carrying out progressive muscle relaxation therapy and deep breathing therapy. In relationship to this, the training assistants had not measured the extent to which the participants were consistent in doing deep breathing therapy, the five-finger relaxation, and progressive muscle relaxation. Progressive muscle relaxation can improve the quality of sleep in the elderly (their satisfaction in their sleep), shorten the time it takes to fall asleep, extend the duration of sleep, make sleep more efficient, and enable them to do more useful daily activities (Sulidah, Yamin, \& Susanti, 2016).

Relaxation therapy could provide a sense of calmness for the training participants because it increased oxygen supply to their brains and increased blood supply to their muscles, thereby reducing tension, improving sleep quality, and increasing their appetite. For the elderly women participants who had experienced decreased physiological functions and were in menopause, which meant that their estrogen levels had reduced, the five-finger relaxation was very useful for refreshing their mind and increasing the blood flow to their muscles.

\section{CONCLUSIONS}

The outcomes of the stress management training using deep breathing technique, the five-finger relaxation, and progressive muscle relaxation had positive impacts on the adult women and elderly women who participated in this community service program. These outcomes were reflected by the scores showing that the signs and symptoms of mental disorders decreased by 0.59 and systolic blood pressure by $21.92 \mathrm{mmHg}$.

\section{ACKNOWLEDGMENTS}

This community service program was named Rumah Pendamping Emak Sehat Jiwa (Ramping Emak Sejiwa) and was carried out with the support of Yogyakarta Muhammadiyah University LP3M (the Office of Research, Publication, and Community Service), which gave the grant for the opportunity for the community service team and helped fund all expenses of the program. This program was also fully supported by UMY Nursing Education Study Program, the elderly cadres in Kalirandu Hamlet, Bangunjiwo Village, Kasihan Subdistrict, Bantul Regency, and all of the participants, who were mothers and the elderly who were very enthusiastic during the training program from the beginning until the end.

\section{REFERENCES}

Arnau-Soler, A., Adams, M. J., Clarke, T.-K., MacIntyre, D. J., Milburn, K., Navrady, L., . . . Major Depressive Disorder Working Group of the Psychiatric Genomics, C. (2019). A validation of the diathesis-stress model for depression in Generation Scotland. Translational Psychiatry, 9(1), 25. DOI: https://doi.org/10.1038/s41398-018-0356-7

Broerman, R. (2018). Diathesis-Stress Model. In Encyclopedia of Personality and Individual Differences (pp. 1-3).

Colodro Conde, L., Couvy-Duchesne, B., Zhu, G., Coventry, W., Byrne, E., Gordon, S., . . . Martin, N. (2019). 44 - A DIRECT TEST OF THE DIATHESIS-STRESS MODEL FOR DEPRESSION. European Neuropsychopharmacology, 29, S805-S806. DOI:

https://doi.org/10.1016/j.euroneuro.2017.08.045

Eliopoulos, C. (2018). Gerontological Nursing. (N. McIntyre, Ed.) (9th ed.). Philadelphia.

Febtrina, R., \& Malfasari, E. (2018). Efek terapi relaksasi nafas dalam dan hipnosis 5 jari terhadap penurunan ansietas pasien heart failure. Journal IPTEK Dan Terapan, 12(4), 250-260. DOI: https://doi.org/10.22216/jit.2018.v12i4.3720

Hartono, D., Somantri, I., \& Februanti, S. (2019). Hipnosis Lima Jari dengan Pendekatan Spiritual Menurunkan Insomnia pada Lansia. Jurnal Kesehatan, $\quad$ 10(2), 187-192. DOI: http://dx.doi.org/10.26630/jk.v10i2.1218 
Kementrian Kesehatan. (2018). Riset Kesehatan Dasar. Indonesia. Retrieved from http://labmandat.litbang.depkes.go.id/images/do wnload/laporan/RKD/2018/Laporan_Nasional_ RKD2018_FINAL.pdf

Kusyati, E., Santi, N. K., \& Hapsari, S. (2018). Kombinasi Relaksasi Napas Dalam dan Aroma Terapi Lavender Efektif menurunkan tekanan darah. In D. Cahyandari (Ed.), Hilirisasi \& Komersialisasi Hasil Penelitian dan Pengabdian Masyarakat untuk Indonesia Berkemajuan (pp. 76-81). Semarang. Retrieved from http://prosiding.unimus.ac.id/index.php/semnas/ article/view/41/41

Li, S., Lloyd, A., \& Ghraham, B. (2019). Physical and mental fatigue across the menstrual cycle in women with and without generalised anxiety disorder. Horm Behavior. DOI: https://doi.org/DOI: 10.1016/j.yhbeh.2019.104667

NANDA. (2018). Nursing Disgnoses Definition and Classification 2018-2020. (T. H. Herdman \& S. Kamitsuru, Eds.) (Eleventh). Stuttgart New York: Thieme New York.

Nova, R. R., \& Tumanggor, R. D. (2018). Pengaruh Terapi Relaksasi Otot Prgogresif terhadap Tingkat Kecemasan Pasien Kanker Payudara di RSUP Haji Adam Malik Medan. Talenta, 1(1), 59-66.

DOI: https://doi.org/10.32734/tm.v1i1.33

PH, L., Daulima, N. helena C., \& Mustikasari. (2018). Relaksasi otot Progresif Menurunkan STress Keluarga yang Merawat Pasien Gangguan Jiwa. Jurnal Keperawatan Indonesia, 21(1), 51-59. DOI: https://doi.org/10.7454/jki.v21i1.362

Psychology. 2020. Diathesis Stress Model-Psychology. parentingforbrain.com/diathesis-stressmodel/\#model. accessed at 5 February 2021.

Rochmawati, D. H. (2017). tekik Relaksasi Otot Progresif untuk Menurunkan Kecemasan. Indonesia.

Solvik, E., Ytrehus, S., Utne, I., \& Grov, E. K. (2019). Pain, fatigue,anxiety, and depression in older home-dwelling people with cancer. Nursing Open, 5(1), 430-438. DOI: https://doi.org/10.1002/nop2.406

Stuart, G. W. (2013). Principles and Practice of Psychiatric Nursing (10th ed.). Charleston, South Carolina: elsevier.

Sulidah, Yamin, A., \& Susanti, R. D. (2016). Pengaruh Latihan Relaksasi Otot Progresif terhadap Kualitas Tidur Lansia The Effect of Progressive Muscle Relaxation Exercise towards Older People' s Quality of Sleep. Jurnal Keperawatan Padjajaran, 4(April), 11-20. DOI: https://doi.org/10.24198/jkp.v4i1.133.g113

Syukri, M. (2019). Efektivitas Terapi Hinosis Lima Jari Terhadap Ansietas Klien Hipertensi di Puskesmas Rawasari Kota Jambi Tahun 2017. Jurnal Ilmiah Universitas Batanghari Jambi,
19(2), 353-365. DOI: https://doi.org/DOI 10.33087/jiubj.v19i2.678

Townsend, M. C. (2011). Nursing DIagnoses in Psychiatric Nursing: Care Plans and Psychotropic Medication. FA Davis Company (8th ed., Vol. 7). Philadelphia: F.A .Davis Company.

Wahyudi, B., Hidayati, L., \& Bakar, A. (2019). Critical Medical and Surgical Nursing Journal ( Jurnal Keperawatan Medikal Bedah dan Kritis ) Pengaruh Hypnosis Auditori Lima Jari terhadap Tanda-Tanda. Jurnal Keperawatan Medikal Bedah Dan Kritis, 8(1), 14-22. Retrieved from https://e-journal.unair.ac.id/CMSNJ

WHO (2019). Proposed working definition of an older person in Africa for the MDS Project. Retrieved from

https://www.who.int/healthinfo/survey/ageingde fnolder/en/

Widaryanti, M. Y., \& Dewi, D. K. (2017). Dukungan Sosial Suami dan Penerimaan Diri dengan Tingkat Stress pada Wanita Menjelang Menopause. Psikologi Teori Dan Terapan, 8(1), 61-67.

DOI: http://dx.doi.org/10.26740/jptt.v8n1.p6167 